\title{
The Intensive Care Medicine clinical research agenda in
}

\section{Paediatrics}

Mark J. Peters ${ }^{1}$, Andrew Argent ${ }^{2}$, Marino Festa ${ }^{3}$, Stéphane Leteurtre ${ }^{4}$, Jefferson Piva ${ }^{5}$, Ann Thompson ${ }^{6}$, Douglas Willson ${ }^{7}$, Pierre Tissières ${ }^{8}$, Marisa Tucci ${ }^{9,10}$, Jacques Lacroix $^{10}$

1. Chair, Paediatric Intensive Care Society Study Group (PICS-SG), UCL Great Ormond Street Institute of Child Health, London, UK <mark.peters@ucl.ac.uk> 2. PICU, Red Cross War Memorial Children's Hospital, School of Child and Adolescent Health, University of Cape Town, Cape Town, Republic of South Africa <andrew.argent@uct.ac.za>

3. Paediatric Intensive Care Unit, the Children's Hospital at Westmead, the Sydney Children’s Hospital Network, NSW, Australia <marino.festa@health.nsw.gov.au> 4. Pediatric Intensive Care Unit, University Lille, CHU Lille, EA 2694, Santé publique: épidémiologie et qualité des soins, F-59000 Lille, France <s-leteurtre@chru-lille.fr> 5. UFRGS University, Medical Director - Pediatric Emergency and Critical Care Department - H Clinicas, Porto Alegre (Brazil) <jpiva@terra.com.br> 6. Executive Committee Chair, Pediatric Acute Lung Injury and Sepsis Investigators (PALISI Network); Children's Hospital of Pittsburgh, Pittsburgh, PA, USA $<$ thompsonae@ccm.upmc.edu> 
7. Executive Committee, PALISI. John Mickell Professor of Pediatric Critical Care, Children's Hospital of Richmond at VCU, Richmond, VA;

\section{douglas.willson@vcuhealth.org.}

8. ESPNIC Scientific Committee Chair; Réanimation Pédiatrique et Médecine Néonatale, Hôpitaux Universitaires Paris-Sud AP-HP, Le Kremlin-Bicêtre, France <pierre.tissieres@bct.aphp.fr>

9. Chair, Pediatric Interest Group, Canadian Critical Care Trials Group <marisa.tucci@gmail.com>

10. Division of Pediatric Intensive Care Medicine, Department of Pediatrics, CHU Sainte-Justine, Université de Montréal, Montréal (Québec) Canada

<Jacques_lacroix@ssss.gouv.qc.ca>

Correspondence: Jacques_lacroix@ssss.gouv.qc.ca

Sainte-Justine Hospital, room 3431

3175 Côte Sainte-Catherine

Montreal (Quebec)

Canada H3T 1C5

Phone: 1-514-345-4931, extension 5556

Fax: 1-514-345-7731

Support: none.

Key words: children, critical care, intensive care, paediatrics, research.

Running title: ICM research agenda: paediatrics 
Title: 67 characters.

Abstracts: 252 words.

Body of the text: 5068 words.

Keywords: 5.

Tables: 3 .

References: 87. 


\section{Abstract}

\section{Background}

Intensive Care Medicine set us the task of outlining a global clinical research agenda for Paediatric Intensive Care (PIC). In line with the clinical focus of the journal we have limited this to research that may influence patient care directly.

\section{Methods}

Clinician researchers from PIC research networks of varied degrees of formality from around the world were invited to answer 2 main questions: 1) What have been the major recent advances in paediatric critical care research? 2) What are the top 10 studies for the next 10 years?

\section{Results}

1) Inclusive databases are well established in many countries. These registries allow detailed observational studies and feasibility testing of clinical trial protocols. Recent trials are larger and more valuable. 2) Most common interventions in PIC are not evidenced-based. Clinical studies for the next 10 years should address this deficit including: ventilation techniques and interfaces; fluid, transfusion and feeding strategies; optimal targets for vital signs; multiple organ failure definitions, mechanisms and treatments; trauma, prevention and treatment; improving safety; comfort of the patient and their family; appropriate care in the face of medical complexity; defining post-PICU outcomes; and improving knowledge generation and adoption, with novel trial design and implementation strategies. 
The group specifically highlighted the need for research in resource-limited environments wherein mortality remains often 10 -fold higher than in wellresourced settings.

Conclusion: Paediatric Intensive Care research has never been healthier but many gaps in knowledge remain. We need to close these urgently. The impact of new knowledge will be greatest in resource-limited environments. 


\section{Introduction}

Research in critically ill patients is difficult; research in critically ill children even more so. Some of this challenge arises from our patients. They are heterogeneous across age ranges and comorbidities, suffer from poorly defined clinical syndromes — just what are sepsis or multiple organ dysfunction syndrome (MODS) exactly? -, exhibit rapidly changing physiology — when deteriorating or recovering - , but still have a low mortality. Further challenges arise from our personalities as paediatric intensivists. The 'doubt everything' mantra of scientist perhaps clashes with the need for a clear thinking and communication in a clinical crisis. Nicholson [1] wrote that "Paediatric intensivists are not strong believers in the scientific method" and Zimmerman [2] describes that we prefer to make empirical decisions inferred from known physiology, saying that paediatric intensivists are "inclined to action rather than deliberate investigation." Moreover, health problems, disease processes and outcomes may be very different in countries with different diseases epidemiology and with different wealth and resources.

This is perhaps true both in the moment of choosing therapies at the bedside but also in planning careers. The problem is not lack of interest in most instances, but rather overwhelming clinical demands or low propensity of granting agencies to finance paediatric studies. The result is that there are relatively few academics in paediatric intensive care. More importantly, most of our practice is not supported by high quality evidence. Even very commonly used interventions such as ventilation, cardiovascular support, sedation, transfusion, fluids and nutrition vary widely between units and individual intensivists. This uncomfortable truth has remained 
largely unobserved because our headline outcome - survival to discharge continues to improve (from $\sim 80-90 \%$ in the 1980's to $>97 \%$ in 2013 in developed countries) [1, 3, 4]. Currently fewer than 1 in 100 admissions in paediatric intensive care units (PICU) globally are recruited in clinical trials; contrasts have been drawn to the 10-fold greater number of clinical trials completed in adult critical care [5]. The Canadian Paediatric Society (CPS) wrote: "Health research is a moral duty because it is the foundation for evidence-based care by all health care practitioners" [6]. Research is not an easy task and it is encumbered by many obstacles. Clinical research is more difficult in children because it "poses important challenges with regard to informed consent and assent, vulnerability and potential conflicts of interest" [6]. In spite of this, research should flourish in PICU. We have higher levels of staffing and much greater resolution of physiological monitoring data and clinical records than other areas. There is no shortage of patients, many of whom receive similar interventions for organ support, and there is a huge potential for lifelong clinical and cost-effectiveness consequences of our care. The scarcity of existing data means that each new study is welcomed and valued.

So where should we be aiming? Should we really target the 'research as a standard of care' [2] approach of iterative randomized controlled trials (RCT) that have transformed the outcomes for acute leukaemia? We would say that this suggestion no longer seems fanciful. Data collection on paediatric critical illness is increasingly formal and standardized. Several research groups in many countries (United Kingdom, United States, Australia and New Zealand, Netherlands, Canada, Italy, etc.) have registries providing case-mix adjusted outcomes data. Submissions 
to some of these like UK PICANet or ANZICS CORE are mandated for funding for PICU services; other are financed by grants and/or private funds, like Virtual PICU (vPICU) (www.chla.org/virtual-picu) in United States and large research programs conducted by members of the Pediatric Acute Lung Injury and Sepsis Investigators (PALISI) Network (www.palisi.org) and of the Canadian Critical Care Trials Group (www.ccctg.ca). These comprehensive databases allow monitoring of performance, planning of service development, and most importantly from the scope of this review, informing on the feasibility of testable specific hypothesis with clinical trials.

Things are changing. The web site http://picutrials.net records RCTs in paediatric intensive care; there have been 337 RCTs published since 1984. While that may seem disappointing, 9\% of these were published in 2015. Yes, most are still single centre studies with 50-150 recruits, but there are an increasing number of collaborative, large multiple centres RCTs undertaken by research collaborations of various degrees of formality (Table 1).

Some funding bodies — such as the National Institute of Health Research in the UK — have shifted some of the focus away from laboratory based basic science research towards pragmatic, real world clinical questions often addressing best use of existing therapies. This may be part of a wider realisation that, to date at least, genomic and stem cell / regenerative medicine advances in many fields have not delivered the anticipated clinical impact. Joyner and colleagues argued in a recent JAMA viewpoint that progress has been inhibited by adherence to this narrative [7]. Readers are likely to have a range of views on this position but we can probably 
agree that if there is a continued move towards pragmatic clinical investigation, then Paediatric Intensivists are especially well positioned to respond.

Intensive Care Medicine set us the task of outlining a global clinical research agenda for Paediatric Intensive Care. This might at first sight appear to be an impossibly difficult request given the diversity of healthcare systems, resources and case-mix. But given the progress developing collaborations mentioned above and perhaps a new recognition of the value of pragmatic research, this might be an opportunity to set our agenda for the next 10 years. The authors here represent a convenience sample of paediatric critical care collaborations, networks or societies from 5 continents with significant research outputs. This is not a definitive list. We took the decision to focus on patient-oriented clinical investigator-led research. The purpose of this article is to reflect on what has been achieved and suggest what might be research priorities for our field globally. We are not aware of previous similar attempts to do this outside North America. Any common ground in priorities and potential for collaboration should be celebrated as an opportunity for more efficient and timely research that increases the potential for generalizability of any results.

\section{What have been the major recent advances in the field?}

\section{Large databases}

Even though there are data to show that there is massive variation in care between units, which may create problems with the understanding of the overall data, formal 
inclusive large databases systematically recording case-mix adjusted outcomes have helped us to understand our practice and have provided feasibility data for randomised trials. Table 2 shows examples of large datasets ( $\geq 1,500$ cases) from collaborative registries and their conclusions.

\section{Recognition of the high morbidity following PICU admission}

In wealthier countries, mortality is no longer the only important outcome from paediatric critical illness. As death before PICU discharge becomes an increasingly rare event (2-6\% in many high resource settings) Pollack and colleagues suggested the need for describing three outcomes: intact survival, new functional morbidity and death [4]. Aspesberro and colleagues [8] confirmed new morbidity in $2-50 \%$ of PICU survivors and compared tools that are now available (PedsQL 4.0 Generic Core Scales, KIDSCR-27, CHQ-PF28 and KINDL) for estimating health-related quality of life in children. Similar many investigators have uncovered a high level of previously unappreciated morbidity in survivors of surgery for congenital cardiac disease and intensive care $[4,9]$.

\section{More conservative use of supportive treatments}

A feature of the findings from well-constructed trials is that they tend to favour (or at least show no harm from) less aggressive care. This pattern can be seen in noninvasive ventilation [10], transfusion thresholds [11, 12], hypothermia for traumatic brain injury [13], glycaemic control [14], and timing of parenteral nutrition [15]. 


\section{Completion of studies in emergency care scenarios}

The last few years we have seen some notable examples of RCTs in challenging timecritical scenarios — something relatively rare in our field previously [16]. Ventura et al [17] in San Paolo studied 120 children with septic shock randomised to epinephrine vs. dopamine as the first line vasoactive drug. They described epinephrine as superior in a case-mix adjusted model (odds ratio, 6.5; 95\%CI, 1.1$37.8 ; \mathrm{p}=0.037)$.

The Therapeutic Hypothermia After Pediatric Cardiac Arrest (THAPCA) investigators published two important RCTs: the Therapeutic Hypothermia After Out-of-Hospital Cardiac Arrest [18] and the Therapeutic Hypothermia After InHospital Cardiac Arrest [19]; both trials showed no advantage of hypothermia $\left(33.0^{\circ} \mathrm{C}\right)$ over active avoidance of fever $\left(36.8^{\circ} \mathrm{C}\right)$. These studies are remarkable achievements especially given that they used prior informed consent with the complexities of achieving this in such pressured scenarios.

\section{Development and validation of consent models suitable for emergency care in}

\section{children}

Alterative approaches to consent in emergency situations and new research about their acceptability are potentially important developments. The use of a 'deferred' or 'delayed' consent process (or more correctly 'research without prior consent') has been studied by Woolfall and colleagues who produced the Connect guidance [20]. Work with parents and families in the UK participating in the catheter-associated infections in children trial [21] and more recently in the Fluid Expansion As 
Supportive Therapy feasibility studies (ISRCTN15244462) suggest a very reassuringly high level of parental support for this approach [22]. This approach does require careful preliminary work, and the interventions represent options that fall within reasonable norms of practice. However, deferred or delayed consent has been determined to be illegal in some jurisdictions (e.g. NSW Clinical and Administrative Tribunal, under the Guardianship Act, Australia). The process of how best to approach families whose child dies after randomisation but before there has been time for a consent discussion is an area of active research.

\section{Important clinical studies in 2016}

The developments described above have assisted recent investigations into core elements of paediatric critical care. An example is The National Emergency Airway Registry for Children (NEAR4KIDS) registry, which has provided invaluable data on safety issues related to intubation. A study of 5,232 children showed that the staff seniority had no impact on the risk of complications of intubation during a cardiac arrest [23]. Family presence during 4,969 tracheal intubations was safe and did not disturb the manoeuvre [24]. However, another study of 3,382 critically ill children with acute respiratory failure showed that the number of tracheal intubation attempts mattered: it was associated with desaturations and increased occurrence of tracheal intubation-associated events [25]. A retrospective study of 2,294 children with in-hospital cardiac arrest showed that survival was lower in patients intubated than not intubated [26]; the conclusion was that their data do not support 
"early tracheal intubation". Extubation is also a concern. A study of 409 children showed that we should not use pressure support during extubation readiness tests [27], and that oesophageal manometry can help detect upper airway obstruction almost immediately after extubation [28].

Similarly we are learning important new facts about the complex intervention of mechanical ventilation. A propensity matched retrospective clinical study that included 20,106 children receiving ventilation for acute lung injury, reported worse outcome and increased hospital costs in the 859 (4.3\%) who received inhaled nitric oxide (NO, 20 ppm during at least 24 hours) [29]; an RCT must be done to study the efficacy of NO in PICU patients with acute lung injury. On the other hand, low cardiac output syndrome ( $15 \%$ vs. $31 \%, \mathrm{p}=0.007)$ ) and ECMO ( 1 vs. $8 \%, \mathrm{p}=0.014)$ were less frequent in 97 children who were exposed to NO (20 ppm) during cardiopulmonary bypass versus 101 who were not [30].

Fivez et al [15] randomised 1,440 critically ill children to receive early parenteral nutrition, (within 24 hours of PICU admission), or late parenteral nutrition, (not before the $8^{\text {th }}$ day in PICU). Fluid input was balanced in the two groups. All patients in Leuwen and Rotterdam received insulin infusions, as did most of them in Edmonton. In the late group, the risk of contracting an infection was $10.7 \%$ while it was $18.5 \%$ in the early group (adjusted odds ratio: 0.48 ; $95 \% \mathrm{CI}: 0.35-0.66$; $\mathrm{p}<0.001)$. PICU stay was shorter in the late than in the early group (6.5 \pm 0.4 vs. 9.2 \pm 0.8 days, $p=0.002)$, as well as the length of mechanical ventilation $(p=0.001)$. The authors concluded that withholding parenteral nutrition is "clinically superior" to early parenteral nutrition. This is probably applicable to all PICU patients who 
received insulin infusion. However, less patients experienced episodes of severe hypoglycaemia (glucose $<40 \mathrm{mg} / \mathrm{dL}$ or $2.22 \mathrm{mmol} / \mathrm{L}$ ) in the early than in the late strategy ( 35 vs. $65, \mathrm{p}=0.001$ ). In the discussion, Fivez and colleagues wrote, "brief episodes of hypoglycaemia... were not shown to have a negative effect on long-term neurocognitive outcomes". This statement is challenged by Sadhwani et al [31] who reported "a possible association between moderate to severe hypoglycaemia and poorer neurodevelopmental outcomes at 1 year of age". The safety of late parenteral nutrition in PICU patients remains to be shown, at least when tight glycaemic control is used.

The efficacy of tight glycaemic control was questioned by the PICS-SG CHiP Investigators [14]. It is again challenged by the Heart And Lung Failure - Pediatric INsulin Titration (Half-PINT) trial [32]. Cardiac surgery patients were excluded in this 35-centre RCT that enrolled 360 critically ill children allocated to a lower-target group (glycaemia between 80 and $110 \mathrm{mg} / \mathrm{dL}$ or $4.4-6.1 \mathrm{mmol} / \mathrm{L}$ ) and 353 , to a higher-target group (150-180 mg/dL or 8.3-10.0 mmol/L). The median number of PICU-free days was similar in the higher- vs. lower target groups: 19.4 days (IQR: 0 to 24.2 ) vs. 19.4 days (IQR, 6.7 to 23.9 ), respectively ( $\mathrm{p}=0.58$ ). There were more infections in the lower group (3.4\% vs. 1.1\%) and more episodes of blood glucose level $<40 \mathrm{mg} / \mathrm{dL}(2.2 \mathrm{mmol} / \mathrm{L})(5.2 \%$ vs. $2.0 \%, \mathrm{p}=0.03)$. The conclusion was that critically ill children with hyperglycaemia do not benefit from tight glycaemic. The remaining question is: what is the cost/benefit of any blood glucose control in PICU patients? 
In the CATCH trial, 1,485 PICU patients were randomised to receive standard central venous catheter (CVC), antibiotic-impregnated CVC or heparin-impregnated CVC; antibiotic-impregnated CVC significantly decreased the risk of bloodstream infections [21]. The efficacy of this measure is clear; what remains to be characterized is its effectiveness.

The Infection Systemic Inflammation Sepsis section of the European Society of Paediatric and Neonatal Intensive Care (ESPNIC) created and validated a new definition of refractory septic shock (RSS) in a cohort of 424 children $(11.6 \%$ mortality) from six PICU. Two RSS scores were created: one was calculated at the bedside, the other one by computer. The area under the receiver operating characteristics curves was 0.920 (95\% CI 0.89-0.94) and 0.956 (95\% CI 0.93-0.97), respectively. A bedside RSS score $\geq 2$ or a computed RSS score $\geq 3.5$ was associated with a significant increase risk of mortality. The RSS can be used to enrol in clinical trials children with severe shock and can be used as an outcome measure in clinical trials run in PICU [33]. More generally, there is an urgent need to validate new definitions of paediatric sepsis and septic shock, especially in countries where the profile of infection is very different than in wealthy countries.

\section{What are the remaining areas of uncertainties?}

Table 3 lists large funded studies currently underway but unpublished in various research collaboratives; this list is not exhaustive, but it gives a flavour of currently funded research priorities [34]. The subjects being studied reflect areas of 
significant uncertainty but also those that have been considered tractable by both researchers and grant panels. This naturally introduces a bias into the subject matter but does reflect those that have met all these demanding standards and are actually in progress. Some themes can be identified in this cluster of studies.

\section{Ventilatory assistance}

Mechanical ventilation is becoming better adapted to patients' needs. For example, modes that assist rather than control patients' own ventilation decrease the respiratory workload and increase patients' comfort. Modes of ventilation like neurally-adjusted ventilatory assist (NAVA) improve patient/ventilator synchrony, and may result in better outcomes [35]. The question of how and when to best use non-invasive ventilation in children is another one for which we need answers; studies on this question are underway (e.g. the FIRST-line support for Assistance in Breathing in Children Feasibility Study).

\section{Resuscitation with fluids}

It is frequently stated that "fluid resuscitation is the gold standard for the initial treatment of early shock" [36]. However, data of the Fluid Expansion As Supportive Therapy (FEAST) study that enrolled 3,141 African children with severe febrile illness and impaired perfusion provided powerful evidence against fluid boluses in low resource environment [37]. What should be the role of fluid bolus in PICU patients? The Canadian 'SQUEEZE' study (septic shock reversal is quicker in paediatric patients randomized to an early goal directed fluid-sparing strategy vs. 
usual care) (NCT01973907) and the UK's 'FiSh' study (Fluids in Shock:

ISRCTN15244462) (UK Health Technology Assessment Programme 13/04/105) may start to fill this evidence gap [38].

\section{Transfusion}

Blood transfusion is the most common procedure performed during hospitalizations in United States (www.ahrq.gov). Severe anaemia increases significantly the risk of death in critically ill patients. Red blood cell transfusion is the only way to treat rapidly such anaemia. However, blood products are overused and misused. We learned in the last decade that it is safe to use a restrictive red blood cell transfusion strategy (threshold haemoglobin for transfusion: $70 \mathrm{~g} / \mathrm{L}$ ) in haemodynamically stable PICU patients without a cyanotic cardiopathy or a congenital anaemia [11]. There are also data suggesting that a threshold of $90 \mathrm{~g} / \mathrm{L}$ is safe in children with stable cyanotic cardiopathy [12]. On the other hand, the risk of mortality was higher in African hospitalized children with respiratory symptoms and with haemoglobin level below $50 \mathrm{~g} / \mathrm{L}$ who were not transfused; this suggests that PICU patients with an haemoglobin level below $50 \mathrm{~g} / \mathrm{L}$ should be transfused [39]. What remains to be determined is what to do in stable children with haemoglobin level between 50 and $70 \mathrm{~g} / \mathrm{L}$, in unstable patients and in patients with some specific diseases like congenital anaemia. The length of storage of red blood cell units (up to 42 days) is another concern. Many paediatric intensivists believe that fresh blood, stored less than a week, is better, even though no hard data support this point of view [40]. Three large RCTs in adults [41-43] and one in very low birth weight premature [44] 
showed that fresh blood offers no advantage, at least up to 28 days of storage. A large international RCT, the Age of Blood in Children in PICU study (ABC-PICU: NCT01977547), should answer the question. The National Heart, Lung and Blood Institute (NHLBI) wrote, "studies on transfusion therapy for pediatric patients... are urgently required" [45]. Accordingly, the NHLBI suggested trial opportunities and priorities in paediatric transfusion medicine: transfusion trigger (red blood cell, plasma and platelets), anaemia tolerance, transfusion in specific population (cardiac surgery, unstable PICU patients), length of storage of blood products, safety, etc. [45, 46].

\section{Understanding vital signs / goal-directed therapy}

Perhaps the most striking deficit in paediatric critical care knowledge is that we do not know the optimal values for vital signs including oxygen saturation, temperature, blood pressure and others even in common scenarios. New highresolution physiological data capture systems offer the potential to understand both physiology and practice in a way that has not been possible previously [47]. More conservative target for vital signs, in line with a general move to more conservative management described above is a subject of active investigations (Table 3).

Physiological targets can be integrated into treatment protocols, and 'goaldirected therapy' is appealing as a way of titrating care to individuals needs. There are more and more data showing that using protocolized prevention or treatment strategy improved patients' outcomes. The main problem with protocols is in defining the best goal to direct therapy. For example, early goal-directed therapy 
aiming to maintain $\mathrm{ScvO}_{2}$ over $70 \%$ was suggested as a clinically useful target in children with severe sepsis [48], but recent large RCTs did not support this statement in adults $[49,50]$, perhaps reflecting improvements in standard care. More studies are needed to find the best vital goals in many conditions observed in PICU.

\section{Multiple organ dysfunction syndrome}

The US National Institute of Child Health and Human Development (NICHD) identified two priorities in paediatric critical illness research in 2016 [51]. The first was to improve our knowledge on paediatric MODS. The following questions were raised.

- Can we improve the diagnostic criteria of paediatric MODS?

- What is the epidemiology of paediatric MODS [52]?

- Can we improve our understanding of the pathophysiology of MODS?

- What is the best way to estimate and to monitor the severity of cases of paediatric MODS: scores, biomarkers, technical devices measuring markers like heart rate variability in a continuous fashion $[53,54]$ ?

- Can we improve the prevention and treatment of paediatric MODS?

- What long-term outcomes are associated and/or attributable to MODS [52]? The NICHD launched a request for application in 2016 to support a large research program on paediatric MODS. 


\section{Trauma}

Another priority of the NICHD is "understanding the pathophysiology of pediatric trauma to optimize treatment outcomes and prevent future difficulties in children"; the NICHD added, "research identifying the social and behavioral causes and consequences of pediatric trauma, and the strategies to prevent and mitigate risk for trauma will be high priorities" [51]. All types of trauma will be considered, including physical and psychological child maltreatment [55]. Many initiatives on brain trauma are already on going. For example, finding biomarkers that would help bedside practitioners to estimate the severity of the brain dysfunction and the prognosis of children with traumatic brain injury is a priority [56].

\section{Safety}

Safety is another important concern. Antibiotic overuse contributes to the development of resistance. The National Summit on Overuse held in July 2013 identified five overused treatments that can harm patient safety and quality: antibiotic use for common cold was ranked first (http://www.jointcommission.org/overuse summit/). Starting antibiotic in PICU patients as soon as an infection is suspected is the right thing to do: in critically ill patients, the risk of mortality is increased if antibiotic treatment is delayed [57]. It is because we are slow to stop antibiotics that there is an increased antibiotics pressure and more resistance to antimicrobials. Improving antibiotic use should improve the outcomes of PICU patients and decrease health system expenses.

We expect that many other safety issues will be raised in the forthcoming years. 


\section{Comfort}

In the 80s, we learnt that pain and anxiety could kill children. Later on, we learnt that giving some analgesia and sedation saves life. Thus giving pain-killing and sedative drugs became standard; huge doses are sometimes used. In the last decade, some data suggested that too much analgesia or sedation might be a cause of neurological sequelae, like disturbed cognitive development [58]. Papers can be found in the medical literature on scores or devices estimating the level of sedation and of comfort, and diagnostic criteria of delirium $[59,60]$. We must determine the safety of analgesia and sedation in critically ill children, and learn how to optimize their use in PICU. Better end-of-life and palliative care and more attention to parents' actual experiences are other important concerns.

\section{Children with medical complexity}

Children with medical complexity now comprise more than one-half of PICU admissions in the United States and account for the vast majority of all ICU therapies, including $86 \%$ of mechanical ventilation days, $78 \%$ of arterial catheters, $77 \%$ of central venous catheters, and $89 \%$ of ECMO runs [61]. This population of children gives every indication of growing as intensivists are increasingly adept at preventing death but often leave survivors with complex medical conditions requiring long-term medical care-e.g., children with hypoplastic left heart syndrome [62], bone marrow and solid organ transplant survivors [63-65]. Research on the underlying conditions remains the purview of other subspecialists 
but the recurrent hospital care for these children frequently falls by default to the paediatric intensivist.

Unfortunately paediatric intensivists are poorly equipped both by training and temperament to accept the role of primary caregivers for the children often referred to as "frequent flyers". Children with sickle cell, diabetes, asthma, epilepsy, cerebral palsy, cystic fibrosis, and many other chronic diseases are repeatedly hospitalized in our PICUs at an estimated annual cost of $\$ 7.6$ billion in the United States [61]. Improving the care of these children should be high on our research agenda.

\section{Post-PICU morbidity}

Decreased in short-term mortality of critically ill children resulted in a shift on the outcomes relevant to PICU patients from mortality to post-PICU outcomes. There is growing recognition of the importance of describing long-term outcomes and costeffectiveness analyses. Post-intensive care syndrome - a name suggested by the Society of Critical Care Medicine (SCCM) — includes many complications like vocal cord dysfunction, dyspnea, hypermetabolic syndrome, cardiac arrhythmias, postthrombotic syndrome, bone and muscle pain, neurodevelopmental delay, ICUacquired weakness myopathy, sleep disorder, swallowing and/or feeding problem, weight loss, chronic kidney dysfunction, behaviour problem, post-traumatic stress disorder, depression, anxiety, anaemia, decreased health-related quality of life, etc. The SCCM also defined a post-intensive care syndrome-family, which includes burnout, post-traumatic stress disorder, anxiety, and depression [66, 67]. These 
problems are frequent and under-recognized and they are not addressed most of the time [68].

Preliminary work in palliative care and advanced care planning show promise in clarifying care goals and providing psychological as well as medical support beyond the PICU [69]. The potential value of PICU "follow-up" clinics where consultation with other subspecialists and primary care providers can be coordinated in both time and place is beginning to be considered [70]. Similarly, telemedicine and the Internet offer promise to extend PICU expertise into the homes of chronically ventilated kids and possibly decrease their many emergency department visits and brief hospital admissions [71]. There are data suggesting that peri-PICU and postPICU rehabilitation program can improve the outcome of PICU survivors [9]. The SCCM and the National Institutes for Health (NIH) and Clinical Excellence (NIHCR) recommend organizing post-ICU outpatient clinics in order to diagnose complications and sequelae and to treat them appropriately.

Research is needed on how to better care for these children - how to improve continuity of care, where best to establish a medical home, and how to coordinate care with other subspecialists and (ideally) primary care providers [72]. The following questions must be addressed:

- What are the mid-term and long-term outcomes of children who survive to a PICU stay?

- Can we prevent and/or treat these complications more appropriately? 
- Can we characterize surrogate outcomes that can be monitored in the PICU and that are closely associated not only to PICU mortality, but also to midterm and long-term post-PICU adverse outcomes?

\section{Innovative RCTs / knowledge transfer}

Most RCTs conducted with critically ill children or adults give negative results, i.e. they were unable to determine if a given treatment makes a statistically significant difference. RCTs can be negative because there is a lack of power (too small sample size), by chance alone and/or because there is no efficacy at least within the studied population. For example, many RCTs reported no benefit of hypothermia in severe traumatic brain injury $[13,73]$. It is valuable learning that a treatment shows no efficacy and/or causes more harm than benefit because this answers the question: should this treatment be used? However this answer is limited to the setting, casemix, resources and other practices at the time in the participating centres. We believe that more attention must be paid to innovative designs of RCT in order that more superiority and/or non-inferiority RCTs report statistically significant results: examples of innovative design include large pragmatic RCT, n-of-1 RCT, stepped wedge RCT, cluster RCT, RCT on big data, bayesian RCT and adaptive RCT (a series of papers on innovative RCTs were published in 2016 [74]).

Applying findings of RCTs is also a big challenge. Lack or lag of knowledge application is considered an important problem by the American National Institutes of Health (NIH) and the Canadian Institutes of Health Research (CIHR). Barriers to knowledge transfer can be scientific or administrative, such as lack of leadership; 
barriers can also be due to social, cultural or religious issues. These barriers can be overcome by multifaceted interventions that promote physician behavioural change, i.e. a combination of at least two of the following actions: lectures, audit, feedback, consensus process, educational outreach visits, local opinion leaders, patient-mediated interventions, reminders - manual or computerized-, marketing [75]. How to overcome these barriers to knowledge application must be studied in PICU not only with RCTs, but also with qualitative research, surveys, descriptive studies, evaluative research and cost/benefit analyses.

\section{What the international group of experts recommend as the top}

\section{0 research topics to be studied in the next 10 years and what}

\section{are expected outcomes/results of these studies?}

The authors of this paper believe that much attention must be paid at least to the following 10 research themes. These are likely to change in both response to developments outside of the our speciality - new research including immunisations, gene therapies, factors outside of medicine including changing societal views of what represents value in healthcare, climate change etc..

We again highlight the importance of such studies being performed in low and middle-income countries as well as highly resourced PICUs. Risk and benefit profiles may differ significantly between these settings. 
1. Ventilation: ventilator induced lung injury (VILI); weaning; better interaction between ventilator and patient; non-invasive mechanical ventilation.

2. Fluid therapy, transfusion and feeding strategies: choice of product, thresholds for transfusion, rate, targets and end-points.

3. Treatment guidance: vital signs targets, physiological or laboratory values in specific patient groups at a point in their disease process.

4. Multiple organ dysfunction syndrome (MODS) and sepsis: definition and diagnostic criteria based on validated physiologic and/or laboratory markers, pathophysiology, pathogens that caused very severe disease (example: Ebola virus), treatment, prevention of primary and secondary complications, relationship between MODS and post-ICU outcomes.

5. Trauma: prevention and treatment, including neuroprotection.

6. Safety: better antibiotic use, better monitoring, safer communication strategies, etc.

7. Comfort of patients and their family: sedation, analgesia, occupational therapy, palliative care, prevention of anxiety, depression, family experience in intensive care, etc.

8. Children with medical complexity: underlying conditions, epidemiology, treatment strategy, and ethical consideration.

9. Post-PICU outcomes: new morbidity post-PICU, quality of life, early rehabilitation, etc. 
10. Knowledge generation and application: when should we use innovative clinical trials and can we improve knowledge transfer by a better comprehension of how physicians make their decisions and by providing better decision support tools?

This list is neither exhaustive nor exclusive, but it is supported by recent clinical trials (Tables 1 and 2) and on-going RCTs (Table 3). The ranking is not important: the tenth bullet (knowledge application) is as important as the first one (ventilation).

In developed countries, we do not expect an important decrease in the mortality rate presently observed in PICU, but it is hoped that post-PICU health status will be better characterized and that the prevention and treatment of mid-term and longterm post-PICU complications will be improved. Moreover, given the exploding costs of critical care, the focus on health care value must be increased. In countries that are less wealthy, mortality is still high; a research agenda specific to critically ill children in these areas must be the highest priority. 


\section{List of abbreviations}

95\%CI: 95\% confidence interval

CVC: central venous catheter

ICU: intensive care unit

MODS: multiple organ dysfunction syndrome

NO: nitric oxide

PICU: paediatric ICU

RCT: randomized controlled trial

RSS: refractory septic shock

SCCM: Society of Critical Care Medicine 
Competing interests, source of funding

None. 


\section{Authors' contribution}

MP and JL drafted the manuscript. All authors read, improved and approved the final version of the manuscript. 


\section{Tables}

\begin{tabular}{|l|l|l|l|}
\hline Table 1. Multiple centre randomised controlled trials recruiting more than 1,000 critically ill children \\
\hline $\begin{array}{l}\text { Research Network / } \\
\text { Collaborative Group / } \\
\text { Registry / Database }\end{array}$ & Study Title & Participants & Findings \\
\hline No group [15] & Early versus late parenteral nutrition in critically ill children & 1,440 & $\begin{array}{l}\text { In critically ill children, withholding parenteral nutrition } \\
\text { for 1 week in the ICU was clinically superior to providing } \\
\text { early parenteral nutrition. }\end{array}$ \\
\hline $\begin{array}{l}\text { PICS-SG: CATCH trial } \\
\text { investigators [21] }\end{array}$ & $\begin{array}{l}\text { Impregnated central venous catheters for prevention of } \\
\text { bloodstream infection in children (the CATCH trial): a } \\
\text { randomised controlled trial }\end{array}$ & 1,485 & $\begin{array}{l}\text { Antibiotic-impregnated central venous catheters } \\
\text { significantly reduced the risk of blood stream infections } \\
\text { compared to standard and heparin central venous } \\
\text { catheters }\end{array}$ \\
\hline $\begin{array}{l}\text { PICS-SG CHiP Investigators } \\
\text { [14] }\end{array}$ & $\begin{array}{l}\text { A randomized trial of hyperglycemic control in pediatric } \\
\text { intensive care }\end{array}$ & 1,369 & $\begin{array}{l}\text { Tight glycemic control in critically ill children had no } \\
\text { significant effect on major clinical outcomes, although the } \\
\text { incidence of hypoglycemia was higher with tight glucose } \\
\text { control than with conventional glucose control }\end{array}$ \\
\hline $\begin{array}{l}\text { Pediatric SCRUB Trial Study } \\
\text { Group [76] }\end{array}$ & $\begin{array}{l}\text { Daily chlorhexidine bathing to reduce bacteraemia in } \\
\text { critically ill children: a multicentre, cluster-randomised, } \\
\text { crossover trial. }\end{array}$ & 4,947 & $\begin{array}{l}\text { Critically ill children receiving daily chlorhexidine bathing } \\
\text { had a lower incidence of bacteraemia compared with } \\
\text { those receiving a standard bathing routine. }\end{array}$ \\
\hline $\begin{array}{l}\text { PALISI network [60] } \\
\text { Protocolized sedation vs usual care in pediatric patients } \\
\text { rechanically ventilated for acute respiratory failure: a } \\
\text { randomized clinical trial (RESTORE) }\end{array}$ & $\begin{array}{l}\text { Among children undergoing mechanical ventilation for } \\
\text { acute respiratory failure, the use of a sedation protocol } \\
\text { compared with usual care did not reduce the duration of } \\
\text { mechanical ventilation. }\end{array}$ \\
\hline PALISI: pediatric acute lung injury and sepsis investigators; PICS-SG: Paediatric Intensive Care Society Study Group.
\end{tabular}




\begin{tabular}{|c|c|c|c|}
\hline $\begin{array}{l}\text { Research Network / } \\
\text { Collaborative Group / Registry / } \\
\text { Database }\end{array}$ & Study Title & Participants & Findings \\
\hline $\begin{array}{l}\text { American Heart Association's Get } \\
\text { With The Guidelines-Resuscitation } \\
\text { Investigators [26] }\end{array}$ & $\begin{array}{l}\text { Association between tracheal intubation } \\
\text { during pediatric in-hospital cardiac arrest and } \\
\text { survival }\end{array}$ & 2,294 & $\begin{array}{l}\text { The study findings do not support the current emphasis on early } \\
\text { tracheal intubation for paediatric in-hospital cardiac arrest. }\end{array}$ \\
\hline ANZICS Paediatric Study Group & $\begin{array}{l}\text { Mortality related to invasive infections, sepsis, } \\
\text { and septic shock in critically ill children in } \\
\text { Australia and New Zealand, 2002-13: a } \\
\text { multicentre retrospective cohort study }\end{array}$ & 97,127 & $\begin{array}{l}\text { Severe infections remain a major cause of mortality in paediatric } \\
\text { ICUs, representing a major public health problem. }\end{array}$ \\
\hline $\begin{array}{l}\text { ANZICS Paediatric Study Group } \\
\text { [78] }\end{array}$ & $\begin{array}{l}\text { Variation in duration of respiratory support } \\
\text { among Australian and New Zealand paediatric } \\
\text { intensive care units }\end{array}$ & 31,358 & $\begin{array}{l}\text { There is unit-level variation in length of stay and duration of } \\
\text { respiratory support, not accounted for by case-mix. }\end{array}$ \\
\hline ANZICS PSG and PICANET [79] & $\begin{array}{l}\text { Paediatric index of mortality } 3: \text { an updated } \\
\text { model for predicting mortality in paediatric } \\
\text { intensive care }\end{array}$ & 53,112 & $\begin{array}{l}\text { Paediatric Index of Mortality } 3 \text { provides an international standard } \\
\text { based on a large contemporary dataset for the comparison of risk- } \\
\text { adjusted mortality among children admitted to intensive care. }\end{array}$ \\
\hline CPCCRN [80] & $\begin{array}{l}\text { The Pediatric Risk of Mortality Score: Update } \\
2015\end{array}$ & 10,078 & $\begin{array}{l}\text { The new Pediatric Risk of Mortality (PRISM) IV algorithm for } \\
\text { survival and death has excellent prediction performance. }\end{array}$ \\
\hline GFRUP [81] & $\begin{array}{l}\text { PELOD-2: an update of the PEdiatric Logistic } \\
\text { Organ Dysfunction score }\end{array}$ & 3,671 & $\begin{array}{l}\text { PELOD-2 score allows assessment of the severity of cases of MODS } \\
\text { in PICU with a continuous scale. The PELOD-2 score now includes } \\
\text { mean arterial pressure and lactataemia in the cardiovascular } \\
\text { dysfunction, and does not include hepatic dysfunction. }\end{array}$ \\
\hline ICCON Investigators [82] & $\begin{array}{l}\text { Impact of operative and postoperative factors } \\
\text { on neurodevelopmental outcomes after cardiac } \\
\text { operations }\end{array}$ & 1,770 & $\begin{array}{l}\text { Operative factors may be less important than innate patient and } \\
\text { preoperative factors and postoperative events in predicting early } \\
\text { neurodevelopmental outcomes after cardiac operations in infants. }\end{array}$ \\
\hline PALISI Network (SPROUT) [83] & $\begin{array}{l}\text { Global Epidemiology of Pediatric Severe } \\
\text { Sepsis: the Sepsis PRevalence, OUtcomes, and } \\
\text { Therapies Study }\end{array}$ & 6,925 & $\begin{array}{l}\text { Pediatric severe sepsis remains a burdensome public health } \\
\text { problem, with prevalence, morbidity, and mortality rates similar to } \\
\text { those reported in critically ill adult populations. International } \\
\text { clinical trials targeting children with severe sepsis are warranted. }\end{array}$ \\
\hline PALISI Network (NEAR4KIDS) [24] & Family presence during pediatric tracheal & 4,969 & Family presence during tracheal intubation can safely be \\
\hline
\end{tabular}




\begin{tabular}{|c|c|c|c|}
\hline & intubations & & implemented as part of family-centred care model in the PICU. \\
\hline PALISI Network (NEAR4KIDS) [23] & $\begin{array}{l}\text { Cardiac arrests associated with tracheal } \\
\text { intubations in PICUs: a multicenter cohort } \\
\text { study }\end{array}$ & 5,232 & $\begin{array}{l}\text { Tracheal-intubation cardiac arrests occurred during } 1.7 \% \text { of PICU } \\
\text { tracheal intubations. Acute hemodynamic instability and oxygen } \\
\text { failure are risk factors. }\end{array}$ \\
\hline PICANet [84] & $\begin{array}{l}\text { Effect of specialist retrieval teams on outcomes } \\
\text { in children admitted to paediatric intensive } \\
\text { care units in England and Wales: a } \\
\text { retrospective cohort study. }\end{array}$ & 57,997 & $\begin{array}{l}\text { These findings support the policy of combining centralisation of } \\
\text { intensive care services for children with transfer by specialist } \\
\text { retrieval teams. }\end{array}$ \\
\hline PICANet [85] & $\begin{array}{l}\text { Characteristics and outcome of children } \\
\text { admitted to adult intensive care units in } \\
\text { England, Wales and Northern Ireland (1996- } \\
\text { 2011). }\end{array}$ & 13,430 & $\begin{array}{l}\text { The number of children admitted to adult intensive care units in } \\
\text { England, Wales and Northern Ireland has been steadily declining } \\
\text { since } 1996 .\end{array}$ \\
\hline $\begin{array}{l}\text { Society of Thoracic Surgeons } \\
\text { Congenital Heart Surgery Database } \\
\text { [86] }\end{array}$ & $\begin{array}{l}\text { Congenital heart surgery case mix across North } \\
\text { American centres and impact on performance } \\
\text { assessment }\end{array}$ & 112,140 & $\begin{array}{l}\text { There is wide variation in congenital heart surgery case mix across } \\
\text { centres. }\end{array}$ \\
\hline $\begin{array}{l}\text { TIPNet Study Group, Italian } \\
\text { permanent registry [87] }\end{array}$ & $\begin{array}{l}\text { The importance of mortality risk assessment: } \\
\text { validation of the Pediatric Index of Mortality } 3 \\
\text { score }\end{array}$ & 11,109 & $\begin{array}{l}\text { Mortality indices require validation in each country where it is } \\
\text { used. The new Pediatric Index of Mortality } 3 \text { score performed well } \\
\text { in an Italian population. }\end{array}$ \\
\hline $\begin{array}{l}\text { Virtual Pediatric Systems database } \\
\text { [29] }\end{array}$ & $\begin{array}{l}\text { Effect of inhaled nitric oxide on outcomes in } \\
\text { children with acute lung injury: propensity } \\
\text { matched analysis from a linked database }\end{array}$ & 20,106 & $\begin{array}{l}\text { Inhaled nitric oxide administration is not associated with } \\
\text { improved mortality in mechanically ventilated children with acute } \\
\text { lung injury. }\end{array}$ \\
\hline
\end{tabular}




\begin{tabular}{|c|c|c|c|c|c|c|c|}
\hline $\begin{array}{l}\text { Research } \\
\text { Network / } \\
\text { Collaborative } \\
\text { Group } \\
\end{array}$ & Study Title & $\begin{array}{l}\text { Trials } \\
\text { Registration } \\
\end{array}$ & $\begin{array}{c}\text { Number } \\
\text { of } \\
\text { Centres } \\
\end{array}$ & $\begin{array}{c}\text { Recruit- } \\
\text { ment }\end{array}$ & Intervention & $\begin{array}{l}\text { Primary } \\
\text { Outcome } \\
\text { Measure } \\
\end{array}$ & Status \\
\hline ANZICS PSG & $\begin{array}{l}\text { Sedation Practice in Paediatric } \\
\text { Intensive Care in Australia and } \\
\text { New Zealand: } \\
\text { Baby-SPICE Pilot Study }\end{array}$ & $\begin{array}{l}\text { ACTRN12614000 } \\
225617\end{array}$ & 8 & 60 & $\begin{array}{l}\text { Comparison of current sedation } \\
\text { practice with a dexmedetomidine } \\
\text { based sedation regimen that } \\
\text { minimizes benzodiazepines }\end{array}$ & $\begin{array}{l}\text { Feasibility } \\
\text { (separation } \\
\text { between groups } \\
\text { for light sedation } \\
\text { in first } 48 \text { hours) }\end{array}$ & Analysis \\
\hline CCCTG & $\begin{array}{l}\text { EPOCH / Evaluating Processes of } \\
\text { Care \& the Outcomes of Children } \\
\text { in Hospital }\end{array}$ & NCT01260831 & 22 & 100,000 & $\begin{array}{l}\text { Implementation of Bedside } \\
\text { Paediatric Early Warning System } \\
\text { (PEWS) vs. standard care }\end{array}$ & $\begin{array}{l}\text { All cause } \\
\text { hospital } \\
\text { mortality }\end{array}$ & Analysis \\
\hline CCCTG & SQUEEZE Trial & Pending & 8 & 0 & $\begin{array}{l}\text { Fluid Sparing Resuscitation } \\
\text { Strategy }\end{array}$ & $\begin{array}{l}\text { Difference in } \\
\text { time to shock } \\
\text { reversal }\end{array}$ & Ready to start \\
\hline CCCTG & $\begin{array}{l}\text { STRIPES / Steroid Use in } \\
\text { Pediatric Fluid and Vasoactive } \\
\text { Infusion Dependent Shock - Pilot } \\
\text { Study }\end{array}$ & NCT02044159 & 7 & 57 & Hydrocortisone vs. placebo & $\begin{array}{l}\text { Feasibility } \\
\text { (patient accrual } \\
\text { rate over one } \\
\text { year) }\end{array}$ & Analysis \\
\hline GFRUP & $\begin{array}{l}\text { Efficacy of IntraVenous } \\
\text { ImmunoGlobulins in Toxic Shock } \\
\text { Syndromes: a Paediatric Pilot } \\
\text { Study (IVIG) }\end{array}$ & NCT02219165 & 9 & 15 & $\begin{array}{l}\text { Randomized trial: intravenous } \\
\text { human immunoglobulin vs. } \\
\text { albumin }\end{array}$ & $\begin{array}{l}\text { Feasibility } \\
\text { (patient accrual } \\
\text { rate over two } \\
\text { year) }\end{array}$ & Recruitment \\
\hline PICS-SG & $\begin{array}{l}\text { "SCARF" / Randomised Study of } \\
\text { Early CPAP in Acute Respiratory } \\
\text { Failure in Children with } \\
\text { Impaired Immunity }\end{array}$ & ISRCTN82853500 & 3 & 42 & $\begin{array}{l}\text { Early ICU admission for CPAP vs. } \\
\text { standard care }\end{array}$ & $\begin{array}{l}\text { Need for } \\
\text { intubation }\end{array}$ & Analysis \\
\hline PICS-SG & $\begin{array}{l}\text { FIRST-ABC / First-line support } \\
\text { for Assistance in Breathing in } \\
\text { Children feasibility study }\end{array}$ & NCT02612415 & 3 & 121 & $\begin{array}{l}\text { High flow humidified oxygen vs. } \\
\text { CPAP }\end{array}$ & $\begin{array}{l}\text { Recruitment } \\
\text { (feasibility of a } \\
\text { definitive study) }\end{array}$ & $\begin{array}{l}\text { Recruitment } \\
\text { complete } \\
\text { Data }\end{array}$ \\
\hline
\end{tabular}




\begin{tabular}{|c|c|c|c|c|c|c|c|}
\hline & & & & & & & validation \\
\hline PICS-SG & FiSh / Fluid in Shock study & ISRCTN15244462 & 4 & 108 & $\begin{array}{l}\text { Pilot randomised controlled study } \\
\text { of conservative vs. liberal fluid } \\
\text { resuscitation in shock study }\end{array}$ & $\begin{array}{l}\text { Recruitment } \\
\text { (feasibility of a } \\
\text { definitive study) }\end{array}$ & $\begin{array}{l}\text { Open to } \\
\text { recruitment }\end{array}$ \\
\hline PICS-SG & $\begin{array}{l}\text { Oxy-PICU / A Randomised Pilot } \\
\text { Multiple Centre Trial of } \\
\text { Conservative versus Liberal } \\
\text { Oxygenation Targets in Critically } \\
\text { Ill Children }\end{array}$ & $\begin{array}{l}\text { ISRCTN in } \\
\text { progress }\end{array}$ & 3 & 120 & $\begin{array}{l}\text { Oxygen saturation targets } 88-92 \% \\
\text { vs. } 95-100 \%\end{array}$ & $\begin{array}{l}\text { Recruitment } \\
\text { (feasibility of a } \\
\text { definitive study) }\end{array}$ & $\begin{array}{l}\text { Recruiting } \\
\text { from January } \\
\text { to August } \\
2017\end{array}$ \\
\hline PICS-SG & $\begin{array}{l}\text { Fever / A Randomised Pilot } \\
\text { Multiple Centre Trial of } \\
\text { Conservative versus Liberal } \\
\text { approach to fever in Critically Ill } \\
\text { Children with suspected infection }\end{array}$ & $\begin{array}{l}\text { ISRCTN in } \\
\text { progress }\end{array}$ & 4 & 125 & Treat fever at $37.5^{\circ} \mathrm{C}$ vs. $39.5^{\circ} \mathrm{C}$ & $\begin{array}{l}\text { Recruitment } \\
\text { (feasibility of a } \\
\text { definitive study) }\end{array}$ & \\
\hline PICS-SG & $\begin{array}{l}\text { SANDWICH/ Cluster Randomised } \\
\text { Trial Sedation and Weaning in } \\
\text { Children }\end{array}$ & In progress & 15 & $\begin{array}{l}12,000- \\
14,000\end{array}$ & $\begin{array}{l}\text { Protocol based nurse-led } \\
\text { sedation, weaning and extubation } \\
\text { readiness testing vs. Current care }\end{array}$ & $\begin{array}{l}\text { Duration of } \\
\text { mechanical } \\
\text { ventilation }\end{array}$ & $\begin{array}{l}\text { Recruiting } \\
\text { from Feb } \\
2017 \text {-Augsut } \\
2020\end{array}$ \\
\hline $\begin{array}{l}\text { PALISI / CCCTG } \\
\text { (Blood Net } \\
\text { subgroup) }\end{array}$ & $\begin{array}{l}\text { ABC-PICU / Age of Blood in } \\
\text { Children in PICU }\end{array}$ & NCT01977547 & $>40$ & 1,538 & $\begin{array}{l}\text { Red blood cell units stored } 7 \text { days } \\
\text { or less vs. standard delivery red } \\
\text { blood cell units }\end{array}$ & $\begin{array}{l}\text { New or } \\
\text { progressive } \\
\text { MODS }\end{array}$ & On-going \\
\hline
\end{tabular}

ANZICS PSG: Australia and New Zealand Intensive Care Society Paediatric Study Group; CCCTG: Canadian Critical Care Trials Group; GFRUP : Groupe Francophone de

Réanimation et Urgences pédiatriques; ICU: intensive care unit; MODS: multiple organ dysfunction syndrome; PALISI: pediatric acute lung injury and sepsis investigators;

PICS-SG: Paediatric Intensive Care Society Study Group; PICU: paediatric ICU. 
Fig. 1. Selected Areas of Uncertainty Facing a Paediatric Intensivist at a typical bedside. Clinical Research Evidence is required most, if not all, of the basic processes of critical care for children. (Abbreviations: NIV: Non-invasive ventilation, NAVA: Neurally adjusted ventilatory assist, HFOV: high frequency oscillatory ventilation, APRV: airway pressure release ventilation, Sp02: peripheral oxygen saturations). 


\section{References}

1. Nicholson CE, Gans BM, Chang AC, Pollack MM, Blackman J, Giroir BP, Wilson D, Zimmerman JJ, Whyte J, Dalton HJ, Carcillo JA, Randolph AG, Kochanek PM (2003) Pediatric critical care medicine: Planning for our research future. Pediatr Crit Care Med 4:196-202

2. Zimmerman JJ, Anand KJ, Meert KL, Willson DF, Newth CJ, Harrison R, Carcillo JA, Berger J, Jenkins TL, Nicholson C, Dean JM, Eunice Kennedy Shriver National Institute of Child Health and Human Development, Collaborative Pediatric Critical Care Research Network (2016) Research as a standard of care in the PICU. Pediatr Crit Care Med 17:e13-21

3. Rothstein P, Johnson P (1982) Pediatric intensive care: factors that influence outcome. Crit Care Med 10:34-37

4. Pollack MM, Holubkov R, Funai T, Berger JT, Clark AE, Meert K, Berg RA, Carcillo J, Wessel DL, Moler F, Dalton H, Newth CJ, Shanley T, Harrison RE, Doctor A, Jenkins TL, Tamburro R, Dean JM; Eunice Kennedy Shriver National Institute of Child Health and Human Development Collaborative Pediatric Critical Care Research Network (2015) Simultaneous prediction of new morbidity, mortality, and survival without new morbidity from pediatric intensive care: A new paradigm for outcomes assessment. Crit Care Med 43:1699-1709

5. Choong K, Duffett M, Cook DJ, Randolph AG (2016) The impact of clinical trials conducted by research networks in pediatric critical care. Pediatr Crit Care Med 17:837-844

6. Fernandez C, Canadian Paediatric Society (CPS), Bioethics Committee (2008) Ethical issues in health research in children. Paediatr Child Health 13:707-712

7. Joyner MJ, Paneth N, Ioannidis JP (2016) What happens when underperforming big ideas in research become entrenched. JAMA 316:1355-1356

8. Aspesberro F, Mangione-Smith R, Zimmerman JJ (2015) Health-related quality of life following pediatric critical illness. Intensive Care Med 41:1235-1246

9. Choong K, Al-Harbi S, Siu K, Wong K, Cheng J, Baird B, Pogorzelski D, Timmons B, Gorter JW, Thabane L, Khetani M; Canadian Critical Care Trials Group (2015) Functional recovery following critical illness in children: the "wee-cover" pilot study. Pediatr Crit Care Med 16:310-318

10. Essouri S, Laurent M, Chevret L, Durand P, Ecochard E, Gajdos V, Devictor $D$, Tissières $P$ (2014) Improved clinical and economic outcomes in severe bronchiolitis with pre-emptive nCPAP ventilatory strategy. Intensive Care Med 40:84-91

11. Lacroix J, Hébert PC, Hutchison JH, Hume H, Tucci M, Ducruet T, Gauvin F, Collet JP, Toledano BJ, Robillard P, on behalf of the TRIPICU investigators, for the Canadian Critical Care Trials Group and the Pediatric Acute Lung Injury and Sepsis Investigators (PALISI) Network (2007) Transfusion strategies for patients in pediatric intensive care units. N Engl J Med 356:1609-1619 
12. Cholette JM, Rubenstein JS, Alfieris GM, Powers KS, Eaton M, Lerner NB (2011) Children with single ventricle physiology do not benefit from higher hemoglobin levels following cavopulmonary connection: Results of a prospective, randomized controlled trial of a restrictive $\mathrm{v}$. liberal red cell transfusion strategy. Pediatr Crit Care Med 12:39-45

13. Hutchison JS, Ward RE, Lacroix J, Hébert PC, Barnes MA, Bohn DJ, Dirks PB, Doucette S, Fergusson D, Gottesman R, Joffe AR, Kirpalani HM, Meyer PG, Morris KP, Moher D, Singh RN, Skippen PW, for the Hypothermia Pediatric Head Injury Trial investigators and the Canadian Critical Care Trials Group (2008) Hypothermia therapy after traumatic brain injury in children. N Engl J Med 358:2447-2456

14. Macrae D, Grieve R, Allen E, Sadique Z, Morris K, Pappachan J, Parslow R, Tasker RC, Elbourne D, CHiP Investigators (2014) A randomized trial of hyperglycemic control in pediatric intensive care. N Engl J Med 370:107118

15. Fivez T, Kerklaan D, Mesotten D, Verbruggen S, Wouters PJ, Vanhorebeek I, Debaveye Y, Vlasselaers D, Desmet L, Casaer MP, Garcia Guerra G, Hanot J, Joffe A, Tibboel D, Joosten K, Van den Berghe G (2016) Early versus late parenteral nutrition in critically ill children. N Engl J Med 374:1111-1122

16. Cvetkovic M, Lutman D, Ramnarayan P, Pathan N, Inwald DP, Peters MJ (2015) Timing of death in children referred for intensive care with severe sepsis: implications for interventional studies. Pediatr Crit Care Med 16:410-417

17. Ventura AM, Shieh HH, Bousso A, Góes PF, de Cássia FO, Fernandes I, de Souza DC, Paulo RL, Chagas F, Gilio AE (2015) Double-blind prospective randomized controlled trial of dopamine versus epinephrine as first-line vasoactive drugs in pediatric septic shock. Crit Care Med 43:2292-2302

18. Moler FW, Silverstein FS, Holubkov R, Slomine BS, Christensen JR, Nadkarni VM, Meert KL, Clark AE, Browning B, Pemberton VL, Page K, Shankaran S, Hutchison JS, Newth CJ, Bennett KS, Berger JT, Topjian A, Pineda JA, Koch JD, Schleien CL, Dalton HJ, Ofori-Amanfo G, Goodman DM, Fink EL, McQuillen P, Zimmerman JJ, Thomas NJ, van der Jagt EW, Porter MB, Meyer MT, Harrison R, Pham N, Schwarz AJ, Nowak JE, Alten J, Wheeler DS, Bhalala US, Lidsky K, Lloyd E, Mathur M, Shah S, Wu T, Theodorou AA, Sanders RC Jr, Dean JM; THAPCA Trial Investigators (2015) Therapeutic hypothermia after out-of-hospital cardiac arrest in children. N Engl J Med 372:898-908

19. Moler FW, Silverstein FS, Holubkov R, Slomine BS, Christensen JR, Nadkarni VM, Meert KL, Browning B, Pemberton VL, Page K, Gildea MR, Scholefield BR, Shankaran S, Hutchison JS, Berger JT, Ofori-Amanfo G, Newth CJ, Topjian A, Bennett KS, Koch JD, Pham N, Chanani NK, Pineda JA, Harrison R, Dalton HJ, Alten J, Schleien CL, Goodman DM, Zimmerman JJ, Bhalala US, Schwarz AJ, Porter MB, Shah S, Fink EL, McQuillen P, Wu T, Skellett S, Thomas NJ, Nowak JE, Baines PB, Pappachan J, Mathur M, Lloyd E, van der Jagt EW, Dobyns EL, Meyer MT, Sanders RC Jr, Clark AE, Dean JM; THAPCA Trial Investigators (2017) Therapeutic hypothermia after inhospital cardiac arrest in children. N Engl J Med 376:318-329

20. Woolfall K, Frith L, Gamble C, Gilbert R, Mok Q, Young B, CONNECT advisory group (2015) How parents and practitioners experience 
research without prior consent (deferred consent) for emergency research involving children with life threatening conditions: a mixed method study. BMJ Open 5:e008522

21. Gilbert RE, Mok Q, Dwan K, Harron K, Moitt T, Millar M, Ramnarayan P, Tibby SM, Hughes D, Gamble C; CATCH trial investigators (2016) Impregnated central venous catheters for prevention of bloodstream infection in children (the CATCH trial): a randomised controlled trial. Lancet 387:1732-1742

22. Molyneux S, Njue M, Boga M, Akello L, Olupot-Olupot P, Engoru C, Kigul iS, Maitland K (2013) 'The words will pass with the blowing wind': staff and parent views of the deferred consent process, with prior assent, used in an emergency fluids trial in two African hospitals. PLoS One 8:e54894

23. Shiima Y, Berg RA, Bogner HR, Morales KH, Nadkarni VM, Nishisaki A, National Emergency Airway Registry for Children Investigators (2016) Cardiac arrests associated with tracheal intubations in PICUs: a multicenter cohort study. Crit Care Med 44:1675-1682

24. Sanders RC, Nett ST, Davis KF, Parker MM, Bysani GK, Adu-Darko M, Bird GL, Cheifetz IM, Derbyshire AT, Emeriaud G, Giuliano JS Jr, Graciano AL, Hagiwara Y, Hefley G, Ikeyama T, Jarvis JD, Kamat P, Krishna AS, Lee A, Lee JH, Li S, Meyer K, Montgomery VL, Nagai Y, Pinto M, Rehder KJ, Saito O, Shenoi AN, Taekema HC, Tarquinio KM, Thompson AE, Turner DA, Nadkarni VM, Nishisaki A; National Emergency Airway Registry for Children NEAR4KIDS Investigators; Pediatric Acute Lung Injury and Sepsis Investigators Network (2016) Family presence during pediatric tracheal intubations. JAMA Pediatr 170:e154627

25. Lee JH, Turner DA, Kamat P, Nett S, Shults J, Nadkarni VM, Nishisaki A, Pediatric Acute Lung Injury and Sepsis Investigators (PALISI), National Emergency Airway Registry for Children (NEAR4KIDS) (2016) The number of tracheal intubation attempts matters! A prospective multiinstitutional pediatric observational study. BMC Pediatr 16:58

26. Andersen LW, Raymond TT, Berg RA, Nadkarni VM, Grossestreuer AV, Kurth T, Donnino MW, American Heart Association's Get With The Guidelines-Resuscitation Investigators (2016) Association between tracheal intubation during pediatric in-hospital cardiac arrest and survival. JAMA 316:1786-1797

27. Khemani RG, Hotz J, Morzov R, Flink RC, Kamerkar A, M. L, Rafferty GF, Ross PA, Newth CJ (2016) Pediatric extubation readiness tests should not use pressure support. Intensive Care Med 42:1214-1222

28. Khemani RG, Hotz J, Morzov R, Flink R, Kamerkar A, Ross PA, Newth CJ (2016) Evaluating risk factors for pediatric post-extubation upper airway obstruction using a physiology-based tool. Am J Respir Crit Care Med 193:198-209

29. Gupta P, Richardson T, Hall M, Bertoch D, Hebbar KB, Fortenberry JD, Wetzel RC (2016) Effect of inhaled nitric oxide on outcomes in children with acute lung injury: propensity matched analysis from a linked database. Crit Care Med 44:1901-1909

30. James C, Millar J, Horton S, Brizard C, Molesworth C, Butt W (2016) Nitric oxide administration during paediatric cardiopulmonary bypass: a randomised controlled trial. Intensive Care Med 42:1744-1752 
31. Sadhwani A, Asaro LA, Goldberg C, Ware J, Butcher J, Gaies M, Smith C, Alexander JL, Wypij D, Agus MS (2016) Impact of tight glycemic control on neurodevelopmental outcomes at 1 year of age for children with congenital heart disease: A randomized controlled trial. J Pediatr 174:193-198

32. Agus MS, Wypij D, Hirshberg EL, Srinivasan V, Faustino EV, Luckett PM, Alexander JL, Asaro LA, Curley MA, Steil GM, Nadkarni VM; HALF-PINT Study Investigators and the PALISI Network (2017) Tight glycemic control in critically ill children. N Engl J Med 376:Epub ahead of print

33. Morin L, Ray S, Wilson C, Remy S, Benissa MR, Jansen NJ, Javouhey E, Peters MJ, Kneyber M, De Luca D, Nadel S, Schlapbach LJ, Maclaren G, Tissieres P; ESPNIC Refractory Septic Shock Definition Taskforce, the Infection Systemic Inflammation Sepsis section of ESPNIC (2016) Refractory septic shock in children: a European Society of Paediatric and Neonatal Intensive Care definition. Intensive Care Med 42:1948-1957

34. Peters MJ, Butt W, Tasker RC (2016) Focus on paediatrics. Intensive Care Med 42:1203-1205

35. Ducharme-Crevier L, Beck J, Essouri S, Jouvet P, Emeriaud G (2015) Neurally adjusted ventilatory assist (NAVA) allows patient-ventilator synchrony during pediatric noninvasive ventilation: a crossover physiological study. Crit Care 19:44

36. Piva JP, Garcia PC (2016) Sepsis: from the stone age to nowadays without a precise definition. Pediatr Crit Care Med 17:794-795

37. Maitland K, Kiguli S, Opoka RO, Engoru C, Olupot-Olupot P, Akech SO, Nyeko R, Mtove G, Reyburn H, Lang T, Brent B, Evans JA, Tibenderana JK, Crawley J, Russell EC, Levin M, Babiker AG, Gibb DM; FEAST Trial Group (2011) Mortality after fluid bolus in African children with severe infection. N Engl J Med 364:2483-2495

38. Inwald DP, Butt W, Tasker RC (2015) Fluid resuscitation of shock in children: what, whence and whither? Intensive Care Med 41:1457-1459

39. Kiguli S, Maitland K, George EC, Olupot-Olupot P, Opoka RO, Engoru C, Akech SO, Nyeko R, Mtove G, Reyburn H, Levin M, Babiker AG, Gibb DM, Crawley J (2015) Anaemia and blood transfusion in African children presenting to hospital with severe febrile illness. BMC Med 13:21

40. Spinella PC, Dressler A, Tucci M, Carroll CL, Rosen RS, Hume H, Sloan SR, Lacroix J, Pediatric Acute Lung Injury and Sepsis Investigators Network (2010) Survey of transfusion policies at US and Canadian children's hospitals in 2008 and 2009. Transfusion 50:2328-2335

41. Lacroix J, Hébert PC, Fergusson DA, Tinmouth A, Cook DJ, Marshall JC, Clayton L, McIntyre L, Callum J, Turgeon AF, Blajchman MA, Walsh T, Stanworth S, Campbell H, Capellier G, Tiberghien P, Bardiaux L, van de Watering L, van der Meer N, Sabri E, Vo D, for the ABLE investigators and the Canadian Critical Care Trials Group (2015) Age of transfused blood in critically ill adults. N Engl J Med 372:1410-1418

42. Steiner ME, Ness PM, Assmann SF, Triulzi DJ, Sloan SR, Delaney M, Granger S, Bennett-Guerrero E, Blajchman MA, Scavo V, Carson JL, Levy JH, Whitman G, D’Andrea P, Pulkrabek S, Ortel TL, Bornikova L, Raife T, Puca KE, Kaufman RM, Nuttall GA, Young PP, Youssef S, Engelman R, Greilich PE, Miles R, Josephson CD, Bracey A, Cooke R, McCullough J, 
Hunsaker R, Uhl L, McFarland JG, Park Y, Cushing MM, Klodell CT, Karanam R, Roberts PR, Dyke C, Hod EA, Stowell CP (2015) Effects of redcell storage duration on patients undergoing cardiac surgery. N Engl J Med 372:1419-1429

43. Heddle NM, Cook RJ, Arnold DM, Liu Y, Barty R, Crowther MA, Devereaux PJ, Hirsh J, Warkentin TE, Webert KE, Roxby D, Sobieraj-Teague M, Kurz A, Sessler DI, Figueroa P, Ellis M, Eikelboom JW (2016) Effect of short-term vs. long-term blood storage on mortality after transfusion. N Engl J Med 375:1937-1945

44. Fergusson DA, Hébert P, Hogan DL, LeBel L, Rouvinez-Bouali N, Smyth JA, Sankaran K, Tinmouth A, Blajchman MA, Kovacs L, Lachance C, Lee S, Walker CR, Hutton B, Ducharme R, Balchin K, Ramsay T, Ford JC, Kakadekar A, Ramesh K, Shapiro S (2012) Effect of fresh red blood cell transfusions on clinical outcomes in premature, very low-birth-weight infants: the ARIPI randomized trial. JAMA308:1443-51

45. Spitalnik SL, Triulzi D, Devine DV, Dzik WH, Eder AF, Gernsheimer T, Josephson CD, Kor DJ, Luban NL, Roubinian NH, Mondoro T, Welniak LA, Zou S, Glynn S; State of the Science in Transfusion Medicine Working Groups (2015) 2015 proceedings of the National Heart, Lung, and Blood Institute's State of the Science in Transfusion Medicine symposium. Transfusion 55:2282-2290

46. Glynn SA, Klein HG, Ness PM (2016) The red blood cell storage lesion: the end of the beginning. Transfusion 56:1462-1468

47. Ray S, Rogers L, Raman S, Peters MJ, Oxy-PICU investigators (2016) Liberal oxygenation in paediatric intensive care: retrospective analysis of high-resolution $\mathrm{SpO}_{2}$ data. Intensive Care Med 42:Epub ahead of print

48. de Oliveira CF, de Oliveira DS, Gottschald AF, Moura JD, Costa GA, Ventura AC, Fernandes JC, Vaz FA, Carcillo JA, Rivers EP, Troster EJ (2008) ACCM/PALS haemodynamic support guidelines for paediatric septic shock: an outcomes comparison with and without monitoring central venous oxygen saturation. Intensive Care Med 34:1065-1075

49. ARISE Investigators, ANZICS Clinical Trials Group, Peake SL, Delaney A, Bailey M, Bellomo R, Cameron PA, Cooper DJ, Higgins AM, Holdgate A, Howe BD, Webb SA, Williams P (2014) Goal-directed resuscitation for patients with early septic shock. N Engl J Med 371:1496-1506

50. ProCESS Investigators, Yealy DM, Kellum JA, Huang DT, Barnato AE, Weissfeld LA, Pike F, Terndrup T, Wang HE, Hou PC, LoVecchio F, Filbin MR, Shapiro NI, Angus DC (2014) A randomized trial of protocol-based care for early septic shock. N Engl J Med 370:1683-1693

51. Maholmes V, Tamburro RF, Jenkins TL (2016) Toward a research agenda on pediatric trauma and critical illness. JAMA Pediatr 170:7-8

52. Crow SS, Hartman ME, Lacroix J, Odetola FO, Watson RS (2017) Epidemiology and outcomes of pediatric multiple organ dysfunction syndrome (MODS). Pediatr Crit Care Med 18(suppl):in press

53. Typpo KV, Lacroix J (2017) Monitoring severity of MODS. Pediatr Crit Care Med 18(suppl):in press

54. Typpo KV, Wong H, Finley S, Daniels R, Seely A, Lacroix J (2017) Monitoring severity of MODS: New technologies. Pediatr Crit Care Med 18(suppl):in press 
55. Maholmes V (2015) Championing research on traumatised and injured children. Inj Prev 21:441

56. Wilkinson AA, Simic N, Frndova H, Taylor MJ, Choong K, Fraser D, Campbell C, Dhanani S, Kuehn S, Beauchamp MH, Farrell C, Anderson V, Guerguerian AM, Dennis M, Schachar R, Hutchison JS (2016) Serum biomarkers help predict attention problems in critically ill children with traumatic brain injury. Pediatr Crit Care Med 17:638-648

57. Sievert DMP, Ricks PP, Edwards JRMS, Schneider A, Patel J, Srinivasan A, Kallen A, Limbago B, Fridkin SK, National Healthcare Safety Network (NHSN) Team and Participating NHSN Facilities (2013) Antimicrobialresistant pathogens associated with healthcare-associated infections: summary of data reported to the National Healthcare Safety Network at the Centers for Disease Control and Prevention, 2009-2010. Infect Control Hosp Epidemiol 34:1-14

58. van Zellem L, Utens EM, de Wildt SN, Vet NJ, Tibboel D, Buysse C (2014) Analgesia-sedation in PICU and neurological outcome: a secondary analysis of long-term neuropsychological follow-up in meningococcal septic shock survivors. Pediatr Crit Care Med 15:189-196

59. Traube CS, G., Kearney J, Patel A, Atkinson TM, Yoon MJ, Halpert S, Augenstein J, Sickles LE, Li C, Greenwald B (2014) Cornell Assessment of Pediatric Delirium: a valid, rapid, observational tool for screening delirium in the PICU. Crit Care Med 42:656-663

60. Curley MA, Wypij D, Watson RS, Grant MJ, Asaro LA, Cheifetz IM, Dodson BL, Franck LS, Gedeit RG, Angus DC, Matthay MA; RESTORE Study Investigators and the Pediatric Acute Lung Injury and Sepsis Investigators Network (2015) Protocolized sedation vs usual care in pediatric patients mechanically ventilated for acute respiratory failure: a randomized clinical trial. JAMA 313:379-389

61. Chan T, Rodean J, Richardson T, Farris RW, Bratton SL, DiGennaro JL, Simon TD (2016) Pediatric critical care resource use by children with medical complexity. J Pediatr 177:197-203

62. Tabbutt S, Nord AS, Jarvik GP, Bernbaum J, Wernosvsky G, Gerdes M, Zackai E, Clancy RR, Nicolson SC, Spray TL, Gaynor JW (2008) Neurodevelopmental outcomes after staged palliation for hypoplastic left heart syndrome. Pediatrics 121:476-483

63. Chow EJ, Anderson L, Baker KS, Bhatia S, Guilcher GM, Huang JT, Pelletier W, Perkins JL, Rivard LS, Schechter T, Shah AJ, Wilson KD, Wong K, Grewai SS, Armenian SH, Meacham LF, Mulrooney DA, Castellino SM (2016) Late effects surveillance recommendations among survivors of childhood hematopoietic cell transplantation: A children's oncology group report. Biol Blood Marrow Transplant 22:782-795

64. Yaigi NA (2013) Long-term outcomes after pediatric liver transplantation. Pediatr Gastroenterol Hepatol Nutr 16:207-218

65. Anthony SJ, Pollock Barziv S, Ng VL (2010) Quality of life after pediatric solid organ transplantation. Pediatr Clin North Am 57:539-557

66. Davidson JE, Jones C, Bienvenu OJ (2012) Family response to critical illness: postintensive care syndrome-family. Crit Care Med 40:618-624 
67. Nelson LP, Gold JI (2012) Posttraumatic stress disorder in children and their parents following admission to the pediatric intensive care unit: a review. Pediatr Crit Care Med 13:338-347

68. Needham DM, Davidson J, Cohen H, Hopkins RO, Weinert C, Wunsch H, Zawistowski C, Bemis-Dougherty A, Berney SC, Bienvenu OJ, Brady SL, Brodsky MB, Denehy L, Elliott D, Flatley C, Harabin AL, Jones C, Louis D, Meltzer W, Muldoon SR, Palmer JB, Perme C, Robinson M, Schmidt DM, Scruth E, Spill GR, Storey CP, Render M, Votto J, Harvey MA (2012) Improving long-term outcomes after discharge from intensive care unit: report from a stakeholders' conference. Crit Care Med 40:502-509

69. Liberman DB, Song E, Radbill LM, Pham PK, Derrington SF (2016) Early introduction of palliative care and advanced care planning for children with complex chronic medical conditions: a pilot study. Child Care, Health, and Development 42:439-449

70. Samuel MV, Colville GA, Goodwin S, Ryninks K, Dean S (2015) The value of screening parents for their risk of developing psychological symptoms after PICU: a feasibility study evaluating a pediatric intensive care followup clinic. Pediatr Crit Care Med 16:808-813

71. Casavant DW, McManus ML, Parsons SK, Zurakowski D, Graham RJ (2014) Trial of telemedicine for patients on home ventilator support: feasibility, confidence in clinical management, and use in medical decision-making. J Telemed Telecare 20:441-449

72. Foster CC, Mangione-Smith R, Simon TD (2016) Caring for children with medical complexity: perspectives of primary care providers. J Pediatr Epub ahead of print

73. Williams G, Sherring C, Butt W, Pediatric Study Group of the Australia and New Zealand Intensive Care Society Clinical Trials Group (2015)

Hypothermia for traumatic brain injury in children-A phase II randomized controlled trial. Crit Care Med 43:1458-1466

74. Woodcock J, Ware JH, Miller PW, McMurray JJV, Harrington DP, Drazen JM (2016) Clinical trials series. N Engl J Med 374:2167

75. Grimshaw JM, Eccles MP, Lavis JN, Hill SJ, Squires JE (2012) Knowledge translation of research findings. Implement Sci 7:50

76. Milstone AM, Elward A, Song X, Zerr DM, Orscheln R, Speck K, Obeng D, Reich NG, Coffin SE, Perl TM; Pediatric SCRUB Trial Study Group (2013) Daily chlorhexidine bathing to reduce bacteraemia in critically ill children: a multicentre, cluster-randomised, crossover trial. Lancet 381:1099-1106

77. Schlapbach LJ, Straney L, Alexander J, MacLaren G, Festa M, Schibler A, Slater A, ANZICS Paediatric Study Group (2015) Mortality related to invasive infections, sepsis, and septic shock in critically ill children in Australia and New Zealand, 2002-13: a multicentre retrospective cohort study. Lancet Infect Dis 15:46-54

78. Straney L, Clements A, Alexander J, Slater A, ANZICS Paediatric Study Group (2011) Variation in duration of respiratory support among Australian and New Zealand pediatric intensive care units. Pediatr Crit Care Med 12:9-13

79. Straney L, Clements A, Parslow RC, Pearson G, Shann F, Alexander J, Slater A, ANZICS Paediatric Study Group, Paediatric Intensive Care Audit 
Network (2013) Paediatric index of mortality 3: an updated model for predicting mortality in pediatric intensive care. Pediatr Crit Care Med 14:673-681

80. Pollack MM, Holubkov R, Funai T, Dean JM, Berger JT, Wessel DL, Meert K, Berg RA, Newth CJ, Harrison RE, Carcillo J, Dalton H, Shanley T, Jenkins TL, Tamburro R; Eunice Kennedy Shriver National Institute of Child Health and Human Development Collaborative Pediatric Critical Care Research Network (2016) The Pediatric Risk of Mortality Score: Update 2015. Pediatr Crit Care Med 17:2-9

81. Leteurtre S, Duhamel A, Salleron J, Grandbastien B, Lacroix J, Leclerc F, on behalf of the Groupe Francophone de Réanimation et d'Urgences Pédiatriques (GFRUP) (2013) PELOD-2: an update of the PEdiatric Logistic Organ Dysfunction score. Crit Care Med 41:1761-1773

82. International Cardiac Collaborative on Neurodevelopment (ICCON) Investigators (2016) Impact of operative and postoperative factors on neurodevelopmental outcomes after cardiac operations. Ann Thorac Surg 102:843-849

83. Weiss SL, Fitzgerald JC, Pappachan J, Wheeler D, Jaramillo-Bustamante JC, Salloo A, Singhi SC, Erickson S, Roy JA, Bush JL, Nadkarni VM, Thomas NJ; for the SPROUT Study Investigators and Pediatric Acute Lung Injury and Sepsis Investigators (PALISI) Network (2015) Global epidemiology of pediatric severe sepsis: the Sepsis PRevalence, OUtcomes, and Therapies Study. Am J Respir Crit Care Med 191:1147-1157

84. Ramnarayan P, Thiru K, Parslow RC, Harrison DA, Draper ES, Rowan KM (2010) Effect of specialist retrieval teams on outcomes in children admitted to paediatric intensive care units in England and Wales: a retrospective cohort study. Lancet 376:698-704

85. Ramnarayan P, Patel K, Pappachan J, Purday J, Davis P, Harrison D, Rowan $\mathrm{K}$ (2013) Characteristics and outcome of children admitted to adult intensive care units in England, Wales and Northern Ireland (1996-2011). Intensive Care Med 39:2020-2027

86. Pasquali SK, Wallace AS, Gaynor JW, Jacobs ML, O'Brien SM, Hill KD, Gaies MG, Romano JC, Shahian DM, Mayer JE, Jacobs JP (2016) Congenital heart surgery case mix across North American centers and impact on performance assessment. Ann Thorac Surg 102:1580-1587

87. Wolfler A, Osello R, Gualino J, Calderini E, Vigna G, Santuz P, Amigoni A, Savron F, Caramelli F, Rossetti E, Cecchetti C, Corbari M, Piastra M, Testa R, Coffaro G, Stancanelli G, Gitto E, Amato R, Prinelli F, Salvo I; Pediatric Intensive Therapy Network (TIPNet) Study Group (2016) The importance of mortality risk assessment: validation of the Pediatric Index of Mortality 3 score. Pediatr Crit Care Med 17:251-256 